UDC 316.77

DOI https://doi.org/10.32840/2707-9147.2019.84.4

N. M. LYSYTSIA, Yu. V. BYELIKOVA

\title{
MOTIVES FOR USING SOCIAL NETWORKS (ON THE EXAMPLE OF FACEBOOK)
}

The article is devoted to the research of motives for using social networks. The sociodemographic characteristics of users of the social network Facebook (its Ukrainian segment) were analyzed. The heterogeneity of users of the social network was considered based on data on the spread of their interests, which made it possible to identify four main motives for using the Facebook social network: hedonistic, social, active and professional.

The difference in the prevalence of these motives among male and female audiences were considered. Hedonistic motive is the most common in both audiences, but for the men the core of the motive is "entertainment", instead for women "shopping and fashion" and "entertainment". The social motive for using social networks is quite common, but it is more important for women than men. The biggest difference between male and female audiences is seen in the interest "family and relationships" (one of the least common among the men). The active motive for using social networks is less common compared to hedonistic and social motives; the popularity for both sexes is the interest of «sports and recreation», while "fitness and health" is more common among the female audience. The professional motive for using social networks is quite common in both male and female audiences.

Based on the results of the analysis, recommendations were made to marketers for promoting various product groups on Facebook. Given that the main motive for using the network is the hedonistic motive, the promotion of entertainment services is the most sought after product today and should be targeted at both male and female audiences.

While promoting FMCG Group products, you should not exclude a male audience when targeting, but the recommended ratio will be 1/3 male to $2 / 3$ female audiences, which is a general recommendation for products designed for men and women. While promoting sports and leisure products, it is advisable to target a 50/50 male / female audience.

Given the importance of professional motives for both male and female audiences, you should target your audience 50/50 when promoting the products of categories "business", "industry", "technology". This dependency will remain in the audience's interest in the content of the issue.

The differences in the prevalence of social motive will be a clue to the formation of content and emphasis on values in the process of audience engagement: content dedicated to children and hobbies, hobbies will be interesting to both sexes.

Key words: social media, Facebook users, motives, gender, social media marketing.

The online media, including social networks, are becoming increasingly popular around the world. Their popularity is related, on the one hand, to the availability of various content (information, entertainment) that the user

(C) Lysytsia N. M., Byelikova Yu. V., 2019 
receives promptly, in a convenient form and relevant to their previous experience of interacting with various materials. On the other hand, networks realize specific needs and interests of people in communication (communication can be realized in open or closed interest groups, in a dialogue mode, in a commentary mode), allow people to follow the news about celebrities, new products on brand pages, realize themselves as bloggers / authors, promote their business, and more.

Most scientific works that study the motives for using social networks focus on the coverage of the local context and are empirically confirmed on surveys of young people (mostly students). Thus, the researchers Lin, Kuan-Yu, and Hsi-Peng Lu [8], having student surveys as a base, conclude that enjoyment is the main motive for using social media. The scientists Whiting, Anita and David Williams [10] also come to this conclusion and claim that pleasure drives the use of networks. The work by Heinonen, Kristina [5] describes the differences between passive and active use of social media, which correlates with the types of media consumers highlighted by practices: passive consumers, participants of discussions and content generators.

Seidman, Gwendolyn [9] examined the relationship between the Big Five and the use of Facebook to fulfill belonging and self-presentational needs. Their conclusions are: high agreeableness and neuroticism were the best predictors of belongingness-related behaviors and motivations; extraversion was associated with more frequent use of Facebook to communicate with others; self-presentational behaviors and motivations were best predicted by low conscientiousness and high neuroticism. Results suggest that conscientious individuals are cautious in their online self-presentation. Neuroticism, agreeableness, and extraversion were positively associated with the tendency to express one's actual self. Neuroticism was positively associated with the expression of ideal and hidden self-aspects. The motivation to express these self-aspects mediated the relationship between neuroticism and self-disclosure[9, P. 402]. A.N. Joinson [6] investigates the uses of social networking site Facebook, and the gratifications users derive from those uses.

In the works of Ukrainian scientists, social networks are considered mainly as a form of communication or an agent of socialization. Therefore, despite the considerable number of works devoted to the study of social networks, the motives for using social networks of the Ukrainian segment of Facebook remain insufficiently studied, which makes the problem relevant. By motives we mean the driving forces of behavior, the drive to act, that is, what drives people to use the social network Facebook.

It is interesting to combine real and virtual worlds within social networks, which is not only a source of opportunity and has the advantages of compensating for the disadvantages of one world at the expense of another. There is also a danger, for example, of the appearance of new types of fraud: "phishing" (swindle personal data from unsuspecting or 
inattentive users of the network), "pharming" (secret redirecting of a victim to a false IP address in order to obtain logins and passwords).

According to a USAID-Internews poll ${ }^{1}$ on media consumption, online media and social networks have taken the lead in popularity in Ukraine [2]. The survey found that $68 \%$ of respondents use social networks to get news (comparing with 53\% last year), while television channel popularity and reach fell to $66 \%$ (comparing with $77 \%$ last year). According to the survey results, the share of Ukrainian Internet users has increased: now $85 \%$ of Ukrainians are online, which substantiates the feasibility of studying both the motives for using various social networks and online media, and the specific behavior of online users belonging to different socio-demographic groups.

The purpose of the article is to identify the motives for using social networks based on user data available on Facebook. To achieve this goal, you need to solve the following problems:

1) investigate the place of social networks in the modern society, their role and possible motives for the use of social networks;

2) consider the heterogeneity of users of social networks based on the data about the spread of their hobbies (interests);

3 ) analyze the socio-demographic characteristics of users of the social network Facebook (its Ukrainian segment);

4) provide advice to marketers on promoting various product groups on Facebook.

In Ukraine, Facebook social network, together with Google's search service and the largest video host Youtube, is among the three most popular sites according to Kantar TNS [3].

Table 1

Top 20 sites by visiting (September 2019) [3]

\begin{tabular}{|c|c|c|}
\hline № in rating & site & reach \\
\hline 1 & google.com & 21800980 \\
\hline 2 & youtube.com & 16686530 \\
\hline 3 & facebook.com & 15124150 \\
\hline 4 & wikipedia.org & 12612310 \\
\hline 5 & rozetka.com.ua & 11130270 \\
\hline
\end{tabular}

${ }^{1}$ The survey was conducted by the sociological company InMind, commissioned by the international non-profit organization Internews, which implements the "Media Program in Ukraine" with the financial support of the United States Agency for International Development (USAID). The main purpose of the survey is to study the habits of Ukrainians with regard to media consumption, as well as their confidence in the media, assess the level of media literacy and public awareness of the implementation of reforms in Ukraine. In June-July 2019, the representatives of InMind questioned 4,056 respondents. The sampling error does not exceed $2.5 \%$. 


\begin{tabular}{|c|c|c|}
\hline 6 & privatbank.ua & 10688930 \\
\hline 7 & ukr.net & 9309450 \\
\hline 8 & olx.ua & 9045740 \\
\hline 9 & prom.ua & 8821630 \\
\hline 10 & sinoptik.ua & 7642490 \\
\hline 11 & obozrevatel.com & 6809900 \\
\hline 12 & tsn.ua & 5955130 \\
\hline 13 & instagram.com & 5913070 \\
\hline 14 & 24tv.ua & 4722140 \\
\hline 15 & segodnya.ua & 4674470 \\
\hline 16 & aliexpress.com & 4304280 \\
\hline 17 & gismeteo.com & 4271010 \\
\hline 18 & parimatch.com & 3915360 \\
\hline 19 & ria.com & 3909370 \\
\hline 20 & allo.com & 3899950 \\
\hline
\end{tabular}

Describing the top 20 sites by traffic, it should be noted that they allow you to understand the needs of Ukrainians in the use of the Internet, the areas that are most in demand: information (search engines, news sites, Wikipedia, weather), entertainment-information-communication (video hosting, social networks), e-commerce (online shopping), financial management (internet banking, bookmaker holding).

That is, the motives for using social networks are likely to combine the motives for using the Internet as a whole (information search, entertainment, communication, shopping, financial services management), motives present in offline life (communication, emotional support or vice versa) and specific motives specific only to social networks.

Such specific motives include, for example "social searching" and "social browsing" that are noted by Lampe, C., Ellison, N. and Steinfield [7, P. 167], in their opinion there is distinction between the use of Facebook for "social searching" - finding out information about offline contacts, and "social browsing" - the use of the site to develop new connections, sometimes with the aim of offline interaction. A survey of over 2,000 students, found evidence that the primary use of Facebook was for "social searching" - that is, using Facebook to find out more about people who they have met offline, or who they attend class or share a dormitory with, while the use of Facebook for "social browsing", for instance, to meet someone via the site with the intention of a later offline meeting, or to attend 
an event organized online, scored relatively low amongst their sample [7, P. 168-170].

Golder S. A., Wilkinson D. and Huberman B.A. [4] report that while the vast majority of messages are sent to friends $(90.6 \%)$, a large proportion $(41.6 \%)$ is sent to friends outside of one's local network. This suggests that messaging is used to maintain and build social ties across distances. In comparison, "pokes" (a form of content-free messaging) were primarily exchanged within a network / school $(98.3 \%$ of all pokes were within a network). Scientists [4] argue that friendship ties require little effort or investment to maintain, while messaging with geographically distant friends is used to build social capital. Social capital is known to mean social connections that can serve as a source of benefits. Social capital is a manifestation of socio-cultural conditions, it is a group resource and cannot be measured on an individual level. Thus, social networks are an effective modern tool for building networks and in general represent a micromodel of functioning of society, where various social groups are represented, there is a group dynamics and there are other social processes under study, such as migration, marginalization, inequality, etc.

In support of the opinion that social networks are characterized by the same characteristics as a real non-virtual society can be cited the data by Lampe, C., Ellison, N. and Steinfield that social networking sites like Facebook may also serve a surveillance function, allowing users to "track the actions, beliefs and interests of the larger groups to which they belong" [7, P.167]. The surveillance and «social search» functions of Facebook may, in part, explain why so many Facebook users leave their privacy settings relatively open.

These needs for watching others have made various television reality shows so popular, now this function is accessible to anyone in the social network. The most interesting work that is relevant to our research is the work by

N. A. Joinson [6] that investigates the uses of social networking site Facebook, and the gratifications users derive from those uses. The paper was based on two studies. In the first study, 137 users generated words or phrases to describe how they used Facebook, and what they enjoyed about their use. These phrases were coded into 46 items which were completed by 241 Facebook users in Study 2. Factor analysis identified seven unique uses and gratifications: social connection, shared identities, content, social investigation, social network surfing and status updating. User demographics, site visit patterns and the use of privacy settings were associated with different uses and gratifications [6, P. 1027].

Within that research participants were asked to respond to the following 4 questions: 1) What is the first thing that comes to mind when you think about what you enjoy most when using Facebook? 2) What other words describe what you enjoy about using Facebook? 3) Using single, easy-to-understand terms, what do you use Facebook for? 4) What uses of Facebook are most important to you?[6, P. 1029]. 
The first question, according to the research by A. Joinson, received the following answers: Facebook was used for 1) keeping in touch with friends who are away from home and chatting to people otherwise would have lost contact with; 2) passive contact, social surveillance (virtual people-watching); 3) re-acquiring lost contacts (reconnecting with people I've lost contact with and finding people you haven't seen for a while); 4) communication (being poked, private messages, writing on walls); 5) photographs (tagged in picture, posting pictures, sharing pictures); 6) design related (ease of use); 7) perpetual contact (seeing what people have put as their "status", the continuous updates, seeing what friends have been up to today); 8) making new contacts (talking to singles, getting new friends, joining groups) [6, P. 1029].

That is, from the user's point of view, the use of the Facebook network performs communication tasks (communication, communion, contacts, self presentation and social observation). At the same time, we know that the main motive for using the networks is pleasure. There is a logical question about what combines communication with pleasure. There are several options. First, network communication performs an important function of compensation (makes it possible to realize the need for communication when it is impossible to realize it offline), provides communication in comfortable conditions for people, is easy to realize and provides ease and accessibility of contacts, minimizes negative communication factors (easier to avoid conflict or communication with those whom you do not like). Secondly, if we draw an analogy between food and information, because information is the same food, but not on the physical but intellectual and social level, then the ease, the variety, the accessibility of the various information causes the effect of satisfaction.

For a deeper study of the nature of the use and enjoyment of Facebook, there was conducted a factor analysis of the variables obtained when receiving answers to questions $1-4$ :

First factor contains items predominantly concerned with "keeping in touch", also "surveillance" and maintenance of "weak ties".

The second factor is comprised of three items related to the joining of groups, organization of events and meeting of "like-minded people". It seems to represent a "shared identities" function.

The third factor is related to the posting and viewing of photographs.

Factor four contains items related to content within Facebook - for instance, applications and quizzes.

Factor five contains items akin to both social searching and social browsing identified by Lampe $\mathrm{C}$. The items comprising this factor cover both the use of Facebook to meet or view new people and to find out more about people who are met offline.

Factor six comprises items related to a unique affordance of social networking sites - the ability to view other people's social networks and friends. This ability to find out more about one's acquaintances through 
their social networks forms another important surveillance function, and may also be a method for increasing the size of one's own social network. This specific use is termed 'Social network surfing' here to signify the ability of users to move from one person to another via friend links, although it may also relate closely to a 'process gratification'

Factor seven comprises items related to the newsfeed and status updates within Facebook [6, description of 7 factors are on P. 1030-1034]. The factors presented by A. Joinson give an idea of the reasons for the use of Facebook users, based on the causes of the use and associations with the network, but these motives reflect the functionality of Facebook, instead they do not take into account internal drivers of the users. However, we are inclined to believe that the motives behind the use of the network are the intrinsic characteristics of the individual, namely interests and hobbies.

Let us turn to the study of the Ukrainian Facebook segment.

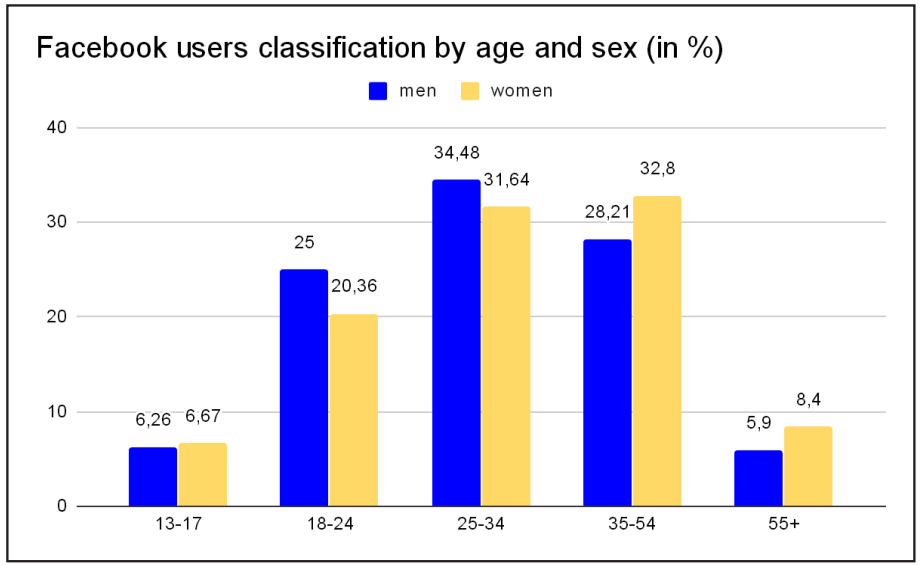

Figure 1. Facebook users age and gender breakdown (\%) (compiled by authors)

Describing the distribution of users by age and gender (the source is the data available to advertisers https://www.facebook.com/advertising/), it should be noted that the age groups 25-34 years (33.33\%), 35-54 years $(32.05 \%)$ and $18-24$ years $(21.79 \%)$ are prevailing among the male audience, groups of 55+ $(8.71 \%)$ and $13-17$ years $(4.1 \%)$ are quite small. Among the female audience, the age distribution is similar: women of 35-54 years old (35.27\%), 25-34 years old $(29.55 \%)$ and $18-24$ years old $(18.11 \%)$ are prevailing, but the $55+$ group is larger compared with a male audience $(12.39 \%)$.

The data shows that the structure of the users is similar to the structure of the population of Ukraine (i.e. it contains all age groups, and it is not 
the youth network), and therefore suitable for promoting products with a diverse target audience.

It necessary to note the rapid growth of the Ukrainian Facebook segment: by October 2019, according to the data available to advertisers (https:// www.facebook.com/advertising/), it is 17.4 million users (7.5 million of them are men and 9.9 million are women). In general, this is in line with the data of international studies that most social network users are women. Compared to 4.5 million users in the whole of Ukraine in October 2015 [1], this increase in audience for 4 years was mainly caused by the ban of the Vkontakte network (which in 2015 was the largest network in Ukraine).

Another difference of the audience compared to 2015: Facebook ceased to be a network of large cities (in 2015 the majority of the audience - 54\% resided in big Ukrainian cities: Kyiv, Odessa, Lviv, Kharkiv, Dnipro) [1]. Now the situation has changed: the number of users in the city of Kiev is 2.9 million, in the Kiev region -810 thousand, in the city of Kharkiv - 900 thousand, in the Kharkiv region - 990 thousand, in the city of Dnipro - 800 thousand. in the Dnipropetrovsk region -1.3 million, in the city of Odessa -920 thousand, in the Odessa region -1 million, in the city of Lviv - 760 thousand, in the Lviv region - 1.1 million.

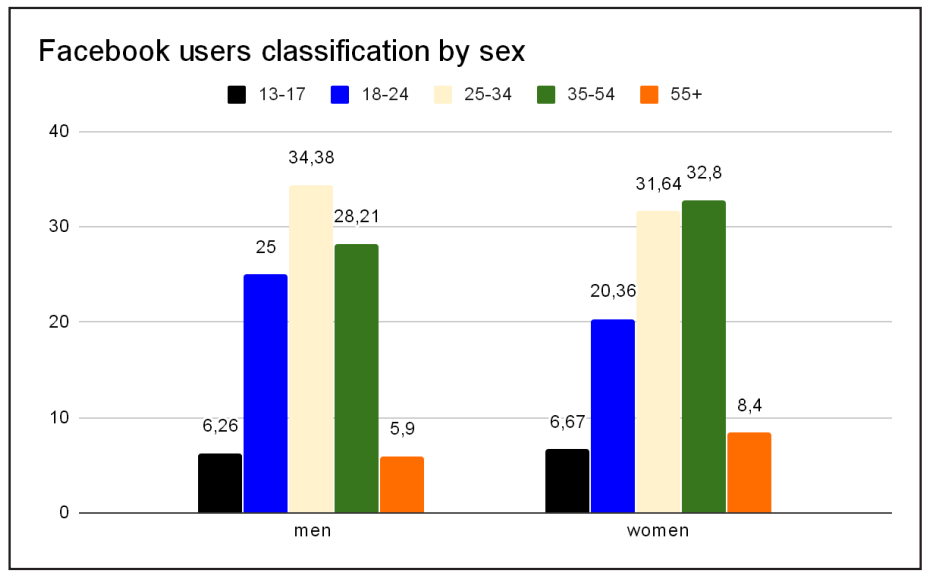

Figure 2. Distribution of Facebook users in groups of men and women (in \%) (compiled by authors)

If we compare the age distribution of Facebook users in the men and women groups, we will see that the most common age group in the male audience is $25-34$ years, while among women 35-54 years, the difference between the 55+ age group is significant. and women $-8.71 \%$ and $12.39 \%$ respectively. That is, the female Facebook audience is older than the male 
audience, perhaps this can be explained by the difference in the average life expectancy of men and women, and the greater involvement of older women (35 years) in social networks. The answer to the question is why older women's involvement rate is higher than that of men, may be given by the study of motives of the use of social networks by users.

In this work, the authors proceeded from the fact that motives (the driving force for the use of the social network) are related to hobbies and interests, because they are the ones that push us to certain types of activities. The Facebook network algorithm allows it to define the enthusiasm and interests of the users with the purpose to show them relevant content, which is then used to target the advertising audience. The data available to network advertisers allows you to see the reach (number of potential audience) by different interests and hobbies, and by gender. We converted the absolute values obtained by interest and gender into relative ones (relative to 7.5 million male and 9.9 million female audiences) and received \% of men and women by each type of interest (see Figure 3).

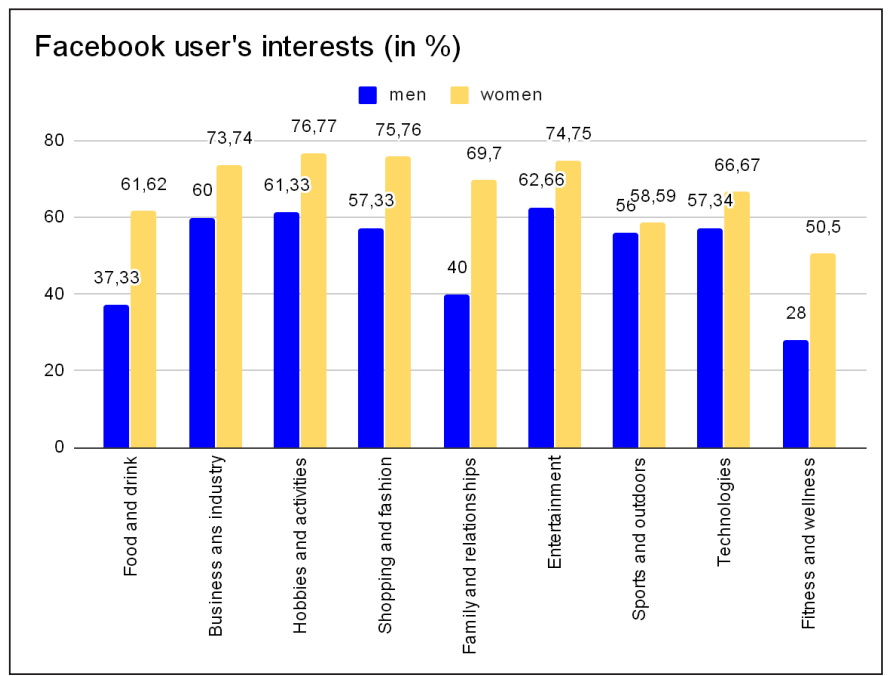

Figure 3. Prevalence of Facebook users' interests in male and female audiences (\%) (compiled by authors)

A meaningful analysis of the provided list of users' hobbies and interests of the users allows us to distinguish certain factors-motives that motivate the use of the Facebook network: hedonistic (combines groups of interests "food and drink", "shopping and fashion", "entertainment"); social ("family and relationships", "hobbies and activities"); active ("fitness and 
wellness", "sports and outdoors") and professional ("business and industry", "technologies").

Let's consider the difference in the prevalence of these motives among male and female audiences. Hedonistic motive is the most common in both audiences, but for the men the core of the motive is "entertainment" (the most common hobby in a male audience), instead for women "shopping and fashion" and "entertainment".

The social motive for using social networks is quite common, but it is more important for women ("hobbies and activities" is the most common interest in a female audience) than men. The biggest difference between male and female audiences is seen in the interest "family and relationships" (one of the least common among the men).

The active motive for using social networks is less common compared to hedonistic and social motives; the popularity for both sexes is the interest of "sports and recreation", while "fitness and health" is more common among the female audience, although for both sexes this is the least common interest.

The professional motive for using social networks is quite common in both male and female audiences. That is, we are seeing changes in traditional gender roles: the interests of "business and industry" and "technology" have ceased to be predominantly male hobbies. It is early to say that the boundaries between gender roles are blurred, gender differences are present, but there is a tendency to blur the boundaries.

The motives distinguished on the basis of interests of users may underlie the functional factors highlighted by A. N. Joinson: social connection, shared identities, content, social investigation, social network surfing and status updating [6].

Thus users derive a variety of uses and gratifications from social networking sites, including traditional content gratification (based on their interests and needs) alongside building social capital, communication, surveillance and social networking surfing. "The different uses and gratifications relate differentially to patterns of usage, with social connection gratifications tending to lead to increased frequency of use, and content gratifications to increased time spent on the site. The variety of uses to which Facebook is put by its users identifies particular challenges for the designers of such sites. For instance, a default privacy setting may be too restrictive for users seeking to meet new people, or who wish to allow new people to discover them" [6, P. 1034].

Based on the analysis of the prevalence of motives for using the social network Facebook, you can provide some recommendations for marketers to promote various product groups in the network. Given that the main motive for using the network is the hedonistic motive, the promotion of entertainment services is the most sought after product today and should be targeted at both male and female audiences.

While promoting FMCG Group products (food, drinks, shopping and fashion), you should not exclude a male audience when targeting, but the 
recommended ratio will be $1 / 3(2 / 3$ advertising budget should be focused on advertising and attracting female audiences), which is a general recommendation for products designed for men and women.

While promoting sports and leisure products, it is advisable to target a 50/50 male / female audience, but instead the "fitness and health" category should follow the male $1 / 3$ targeting principle.

Given the importance of professional motives for both male and female audiences, you should target your audience 50/50 when promoting the products of categories "business", "industry", "technology". This dependency will remain in the audience's interest in the content of the issue.

These differences in the prevalence of social motive will be a clue to the formation of content and emphasis on values in the process of audience engagement: content dedicated to children and hobbies, hobbies will be interesting to both sexes (but the greatest need for such content still exists among women), but the content about relationships and family will be interesting for only $40 \%$ of men and $70 \%$ of women.

Thus, further study of the audience of the Ukrainian segment of the social network Facebook was done, which gives grounds for highlighting the motives for using social networks (hedonistic, social, active, professional) based on the analysis of the hobbies and interests of users, which allowed us to offer recommendations for marketers on promotion of various groups of products online.

In the nearest future, it would be interesting to keep track of the dynamics of the spread of interests in female and male audiences, which capture the change of social roles in society. A comparative analysis of the use of the Facebook social network and other social networks would answer questions about the popularity of these networks and the decision-making process as to their selection.

\section{References}

1. Бєлікова Ю.В. Гендерна специфіка соціальних мереж в Україні як основа для СММ. Маркетинг в Украӥні. 2015. №5. С. 16-21.

2. Онлайн медіа та соціальні мережі перехопили лідерство у телебачення за популярністю в Україні. URL: https://internews.in.ua/uk/news/onlajn-media-ta-sotsialnimerezhi-perehopyly-liderstvo-u-telebachennya-za-populyarnistyu-v-ukrajini-noveopytuvannya-usaid-internews-schodo-spozhyvannya-zmi/?fbclid=IwAR3w9NXp19yuxG XAz108eYzODC2sisls6 NlhQ-jpGcKQA8EAylN7WL2Jes (дата звернення 23.10.2019).

3. Рейтинг популярних сайтів за вересень 2019 URL: https://ns-ua.com/news/ reyting-populyarnih-saytiv-za-veresen-2019 (дата звернення 15.10.2019).

4. Golder S. A., Wilkinson D. and Huberman B.A. Rhythms of Social Interaction: Messaging within a Massive Online Network 3rd International Conference on Communities and Technologies, (2007).

5. Heinonen, Kristina. Consumer activity in social media: Managerial approaches to consumers' social media behavior.Journal of Consumer Behaviour .2011. P. 356-364.

6. Joinson A. N. 'Looking at', 'Looking up' or 'Keeping up with' people? Motives and uses of Facebook/ A.N. Joinson. Proceedings of the SIGCHI conference on Human Factors in Computing Systems. ACM. 2008. P.1027-1036. 
7. Lampe C., Ellison N. and Steinfield C. A Face(book) in the Crowd: Social Searching vs. Social Browsing. In proceedings of ACM Special Interest Group on Computer-Supported Cooperative Work, ACM Press (2006). P. 167-170.

8. Lin, Kuan-Yu, Hsi-Peng Lu. Why people use social networking sites: An empirical study integrating network externalities and motivation theory. Computers in human behavior .2011. P. 1152-1161.

9. Seidman, Gwendolyn. Self-presentation and belonging on Facebook: How personality influences social media use and motivations. Personality and individual differences. 2013. P. 402-407.

10. Whiting Anita, David Williams. Why people use social media: a uses and gratifications approach. Qualitative Market Research : An International Journal .2013. P. 362-369.

\section{Лисиця Н. М., Бєлікова Ю. В. Мотиви використання соціальних мереж (на прикладі Facebook)}

Стаття присвячена вивченню мотивів використання сочіальних мереж. Було проаналізовано сочіально-демографічні характеристики користувачів сочіальної мережі Facebook (іï українського сегмента). Розглянуто гетерогенність користувачів соціальної мережі, трунтуючись на даних про розповсюдженість їх інтересів, щзо дозволило ідентифікувати чотири основні мотиви використання сочіальної мережі Facebook: гедоністичний, сочуільний, активний та професійний, та виділити їх гендерну специфіку.

Розглянуто різницю в почиреності циих мотивів серед чоловічої та жіночої аудиторії. Гедоністичний мотив є найпоширенішим для обох аудиторій, але для чоловіків основою мотиву є «розвага», а для жінок - «шоппінг $і$ мода» та "розвага». Сочіальний мотив використання сочіальних мереж досить поширений, але він важливіший для жінок, ніж чоловіків. Найбільша різниия між чоловічою та жіночою аудиторією спостерігається у інтересах до «сім'ї та стосунків» (однією з найменш поширених серед чоловіків). Активний мотив використання сочіальних мереж зустрічається рідше порівняно з гедоністичними та соціальними мотивами; популярність для обох статей викликає інтерес до "спорту та відпочинку», тоді як «фітнес та здоров'я» частіше зустрічаються серед жіночої аудиторії. Професійний мотив використання сочіальних мереж досить поширений як серед чоловічої, так і жіночої аудиторії.

За результатами проведеного аналізу запропоновані рекомендаціі маркетологам щзодо просування різних груп продуктів у мережі Facebook. Зважаючи на те, щзо основним мотивом використання мережі є гедоністичний мотив, просування розважальних послуг є найбільш затребуваним продуктом сьогодні і має бути орієнтованим як на чоловічу, так $і$ на жіночу аудиторію.

Просуваючи товари FMCG Group, ви не повинні виключати чоловічу аудиторію при націлюванні, але рекомендоване співвідношення становитиме 1/3 чоловічої та 2/3 жіночої аудиторії, що є загальною рекомендачією для продуктів, розроблених для чоловіків і жінок. Просуваючи товари для спорту та дозвілля, дочільно орієнтуватися на 50/50 чоловічу / жіночу аудиторію.

Зважаючи на важливість професійних мотивів як для чоловічої, так і для жіночої аудиторії, слід орієнтуватися на свою аудиторію 50/50 під час просування товарів категорій «бізнес», «галузь», «технології». Ця залежність залититься в інтересах аудиторії до змісту випуску. 
Відмінності в поширеності соціальних мотивів будуть підказкою до формування змісту та акиенту на цінності в прочесі залучення аудиторії: зміст, присвячений дітям та захопленням, захоплення будуть цікаві обом статям.

Ключові слова: соціальні медіа, користувачі Facebook, мотиви, гендер, соиіальний медіа маркетинг.

\section{Лисица Н. М., Беликова Ю. В. Мотивы использования социальных сетей (на примере Facebook) \\ Статья посвящена изучению мотивов использования социальных сетей.} Были проанализированы социально-демографические характеристики пользователей сочиальной сети Facebook (ее украинского сегмента). Рассмотрень гетерогенность пользователей сочииальной сети основываясь на данных о распространенности их интересов, что позволило идентифицировать четыре основных мотива использования сочиальной сети Facebook: гедонистический, соииальный, активный и профессиональный и выделить их гендерную специифику.

Различия в распространенности этих мотивов среди мужской и женской аудитории были рассмотрены. Гедонистический мотив является наиболее распространенным в обеих аудиториях, но для мужчин ядро мотивов "развлечения», а для женщин - «шоппинг и мода» и «развлечения». Соччиальный мотив использования сочиальных сетей довольно распространен, но он важнее для женшин, чем для мужчин. Наибольшая разница между мужской и женской аудиторией проявляется в интересе "семья и отношения» (один из наименее распространенных среди мужчин). Активный мотив использования сочиальных сетей встречается реже по сравнению с гедонистическими и социальными мотивами; популярность для обоих полов вызывает интерес «спорт и отдых», в то время как "фитнес и здоровье» чаще встречаются среди женской аудитории. Профессиональный мотив использования соичильных сетей довольно распространен как для мужской, так и для женской аудитории.

По результатам проведенного анализа предложень рекомендации маркетологам для продвижения различных групп продуктов в сети Facebook. Учитывая, что основнылм мотивом использования сети является гедонистическиймотив, продвижение развлекательных услуг сегодня является наиболее востребованным продуктом и должно быть ориентировано как на мужскую, так и на женскую аудиторию.

При продвижении продуктов FMCG Group не следует исключать мужскую аудиторию при таргетинге, но рекомендуемое соотношение будет составлять от 1/3 мужской до 2/3 женской аудитории, что является общей рекомендаџией для продуктов, предназначенных для мужчин и женщин. При продвижении товаров для спорта и отдыха рекомендуется ориентироваться на аудиторию 50/50 мужчин и женщин.

Учитывая важность профессиональных мотивов как для мужской, так и для женской аудитории, вы должны ориентироваться на свою аудиторию 50/50 при продвижении товаров категорий «бизнес», «отрасль», «технология». Эта зависимость останется в интересе аудитории к содержанию вопроса.

Различия в распространенности сочиальньх мотивов будут ключом к формированию контента и акцентуна ценностях в процессе вовлечения аудитории: контент, посвященный детям и увлечениям, будет интересен обоим полам.

Ключевые слова: социальные медиа, пользователи Facebook, мотивы, гендер, сочиальный медиа маркетинг. 